\title{
Enhancing the heritage conservation by Sustaining Historical Buildings: Hail Palace, as a case study
}

\author{
Abdullah Alorf ${ }^{1}$, Nashwan Al-Ansi² \\ ${ }^{1} \mathrm{MSc}$, candidate, ${ }^{2}$ Asst. Prof. \\ Department of Architecture, College of Architecture and Planning, \\ Qassim University Saudi Arabia \\ eng.a.h.alorf@gmail.com, n.alansi@qu.edu.sa \\ Tel: +966503744333
}

\begin{abstract}
Saudi Arabia has a wealth of heritage buildings that still exist today. Therefore, the need to preserve the architectural heritage of historical and cultural significance is becoming increasingly relevant. In line with the Saudi vision 2030.Thispaper aims to discuss the current situation of the king Abdul-Aziz palace in Hail, to enhance heritage conservation by sustaining historical buildings. Thus, efforts are continuing to evaluate the conservation to arrive at appropriate strategies. Therefore, the case study was chosen to explain the importance of the existing conservation policies to ensure that the heritage buildings are handled to retain their ingenuity.
\end{abstract}

Keywords: Heritage Conservation, Historic Buildings, Architectural Heritage, Preservation.

eISSN: 2398-4287@ 2021. The Authors. Published for AMER ABRA CE-Bsby e-International Publishing House, Ltd., UK. This is an open access article under the CC BYNC-ND license (http://creativecommons.org/licenses/by-nc-nd/4.0/). Peer-review under responsibility of AMER (Association of Malaysian Environment-Behaviour Researchers), ABRA (Association of Behavioural Researchers on Asians/Africans/Arabians) and CE-Bs (Centre for Environment-Behaviour Studies), Faculty of Architecture, Planning \& Surveying, UniversitiTeknologi MARA, Malaysia.

DOI: https://doi.org/10.21834/ebpj.v6i16.2716

\subsection{Introduction}

Within the long history, Saudi Arabia has a diverse range of heritage buildings and sites today (King, 1998). Thus heritage is the reflection of society and culture. Estate our past that has been preserved or conserved, not only for the benefit of the present generation but will also be inherited by future generations (SCTH, 2015). Najd region is one of the richest heritage sites in Arab Saudi. The case study on King Abdul-Aziz palace Hail city, has been applied as the research methodology whereas, the case study area through the Ages, presented a wealth of knowledge, of the region's heritage and the importance of preserving and caring for it; thus, the case study in the area chosen Hail Historic Palace (Al Qieshlah), is a good example that represents the status of applying the conservation policies on the historical heritage buildings in Saudi Arabia in general and Hail city in particular. Therefore, Dealing with the problem of losing the historic building to its original identity is an indicator that should be investigated and examined. So the study will highlight the different causes that led to the failures of the current conservation policies, helping to uncover its effects and contributing to the investment of precious treasures, for these historic buildings. In support of its development path, and guided by its cultural stock. Where king Abdul Aziz palaces are considered and the area one of the best examples that represent the historical period time that contributed to this type of architectural heritage pattern (Faqir, 2015). However, the historical heritage buildings, including King Abdul-Aziz palaces, suffer from natural decay, neglect, and lack of awareness by the public (Al-Rashed, 2002). The paper aims to discuss the current situation of the

eISSN: 2398-4287C 2021. The Authors. Published for AMER ABRA cE-Bsby e-International Publishing House, Ltd., UK. This is an open access article under the CC BYNC-ND license (http://creativecommons.org/licenses/by-nc-nd/4.0/). Peer-review under responsibility of AMER (Association of Malaysian Environment-Behaviour Researchers), ABRA (Association of Behavioural Researchers on Asians/Africans/Arabians) and cE-Bs (Centre for Environment-Behaviour Studies), Faculty of Architecture, Planning \& Surveying, UniversitiTeknologi MARA, Malaysia.

DOI: https://doi.org/10.21834/ebpj.v6i16.2716 
king Abdul-Aziz palace in Hail, with the help of the implementation of conservation policies and evaluate them to arrive at appropriate strategies, to enhance heritage conservation by sustaining historical buildings. Thus to preserve these historic buildings, good conservation policies should be applied, to ensure that the heritage buildings are handled to retain their originality.

\subsection{Literature Review}

The historic environment is one of the programs that were originated by Saudi vision 2030 in 2016. From Saudi vision 2030, it declared that areas with an attractive character and strong sense of identity must be maintained and enhanced; this including historical and heritage buildings (vision2030, 2016). This part provides a review of the background on historical heritage buildings. It begins with a heritage historic Environment, the importance and the responsibility of Historical Heritage Buildings conservation, giving an introduction to heritage conservation Principles, Policies and Guidance, also in this part the study reviews the conditions of the case study Hail Historic Palace (Al Qieshlah), that it was identified as historic building based on the local authority, Hail Municipality (SCTH, 2013).

\subsection{Heritage Historic Environment}

The concept of heritage itself is not easily defined (Aziz, 2017). (Larkham, 1995) defines heritage as: "simply all things to all people". However, there has been much debate on the nature and scope of "built heritage" studies.

"Heritage is one of the most controversial concepts since heritage revealed itself as a various functioning role in our society; the identity of citizens, history of the region, as well as an important destination of the tourism industry, means of community development." (Mason, 2015).

The historic environment is central to Saudi Arabia's cultural heritage and sense of identity, and hence a resource that should be sustained for the benefit of present and future generations. Studying heritage and historic buildings aim to set out a logical approach to making decisions and offering guidance about all aspects of the historic environment, and for reconciling its protection with the economic and social needs and aspirations of the people who live in it. (Alyan,2005).

\subsection{Historical Heritage Buildings}

"Conservation, protection, and restoration of historical/heritage sites and buildings are central to the urgent task of conserving the historical symbolism, cultural values and regional identities of the physical environment, patriotically in educating future generations." (AlSaud, 2013)

A heritage building is generally considered to be a building that has some kind of historical value. Thus, the people in the present are connected to the historic building via past events somehow. The landmark building may hold particular landmark interest because of its importance to a particular historical event or period, or be associated with nationally important people. Furthermore, there might be particular historical interest in the building itself, i.e. its construction methods, design, architectural significance, and so on (Feilden, 1994).

\subsection{Hail Historic Palace (Al Qieshlah).}

Hail city is situated in the central region of the Kingdom of Saudi Arabia in the Najd region and at the same time the city located at the crossroads of the commercial caravan routes. Hail city is an ancient area geologically, the history of settlement in this city dates back to before the tenth millennium $\mathrm{BC}$, and there are also Thamudic and Laiyan monuments and inscriptions in it, among others. Whereas, Hail palace Al Qieshlah (the King Abdul Aziz Palace), which is classified within one of the most essential historical Heritage buildings, and is a symbol of the most phases' present king Abdul-Aziz kingdom at its peak. The enormous size, aesthetic proportions, and style represent an age of emotional strength and rigor. Amidst the unceasing bustle of Hail, stands this colossal monument, evoking nothing but admiration from the onlookers, which is an incredible example of Najd region architecture. According to (King, 1998), indicated in his book -Traditional Architecture of Saudi Arabia- My opinion in compiling this account of a vanishing Arabian building tradition is that within a few years most will be lost, I would prefer to be wrong". Moreover, most previous studies indicated that authorities in the Arab region have a long history of neglect towards the urban heritage stock of their cities and historic buildings (Alkhamis, 2011). Also, in recent years, many of the old buildings that constitute the extant evidence of the indigenous Arabian architectural tradition have disappeared, their building materials were such that maintenance was required quite regularly. The Hail Historic Palace (Al Qieshlah) is one of these historic buildings that suffer from neglect and has not been maintained for a long time.

\subsection{Conservation Principles, Policies and Guidance}

In the early 1970s, there was widespread interest in inbuilt heritage conservation (the Venice Charter), reflecting international awareness of the importance of built heritage sites worldwide to protect the cultural identity and national legacy. Thus globally interest was the base and cornerstone of most of the currently built heritage conservation discourses, and studies worldwide and has influenced conservation policies, strategies, approaches, and schemes everywhere because of the severe decay of the world and national heritage sites globe. (Bagader, 2016). Whereas, the Kingdom's Vision 2030 was in line with UN Resolution 1972, that the protection of the World Cultural and Natural Heritage is an integral part to foster equitable, sustainable development and to enhance peace and security in all human settlements on the land, and to ensure policy coherence with the UN sustainable development agenda as enshrined in the document discussed in 2015 entitled "Transforming our world: the 2030 Agenda for Sustainable Development. (vision2030, 2016). 
Studying the Conservation Principles, Policies, and Guidance are primarily intended to help to ensure that the goals to be achieved in this study are reached, which were referred to in the introduction and also to the consistency of approach in carrying out the right role in the environment of Saudi Arabia. Therefore, making an evaluation specifically, on the current conservation policy helps address the challenges of modernizing heritage protection by proposing an integrated approach to making decisions, based on a typical process. The Principles look forward to the consolidated framework of heritage protection offered in the Saudi vision 2030 (Majidi \& Harith, 2015).

\subsection{Case Study Area and Methods}

\subsection{The Case Study Area}

In this study, the Hail city was selected, because it presented a wealth of knowledge, of the region's heritage. Moreover, the case study in the area chosen Hail Historic Palace (Al Qieshlah), is a good example that represents the status of applying the conservation policies on the historical heritage buildings in Saudi Arabia in general and Hail city in particular. Therefore, the study will bring out the problem of losing the historic building to its original identity, and highlights the different causes that led to the failures of the current conservation policies, helping to uncover its effects and contributing to the investment of precious treasures, for these historic buildings.

\section{2 methods}

To achieve the study aims, the objectives of this study as presented in the literature review section were explained. In order to achieve the identified objectives, an explanation of the currently existing policies, Principles, and Guidance of their contents was covered in the literature section too. Furthermore, the study shed light on Hail Historic Palace (Al Qishlah), as one of the most important historical buildings in the Najd region. This is necessary to generally understand the important causes when dealing with the topic of evaluation of the conservation policies. Drawing from the review of the literature with respect to the research strategies used in similar studies, the research methods adopted for this study were both quantitative and qualitative surveys (Osuala 2001). The three principal survey techniques used were site observation, photographs, and in-depth interviews. The choice of these survey techniques enabled to evaluate and discover the different causes that led to the failures of the current conservation policies that applied to these historical heritage buildings. Based on that, data used in this study were collected from both primary and secondary sources. Therefore, the primary data of this study are gathered through in-depth interviews (both formal and informal), with specialists, architects, three officials, five administrators in the local authority, who are also familiar with the case study area. On the other hand, the observation, and phototracking was conducted as some of the narratives were unable to completely narrate the story, the photo tracking method was used to explain the whole story.

\subsection{Results and Discussion}

\subsection{The current situation of the case study King Abdul-Aziz Palace in Hail (Observation)}

The observation was prepared basically to record observations made by the researcher during the field work. This data collection instrument was used in the collection of data pertaining to the physical characteristic of the case study Hail Historic Palace (Al Qieshlah), with an attractive character and strong sense of identity estates investigated. Among the data this instrument was designed to collect be the location of the historic building, the building layout, and Construction material and technique. From the above, A number of points apparent as will be in the follows:

\section{a. Location}

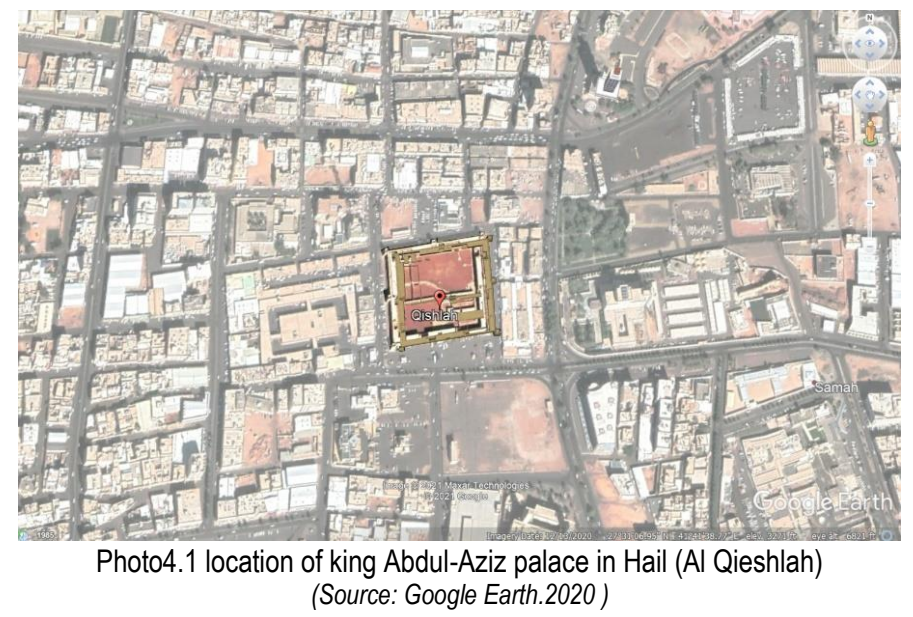




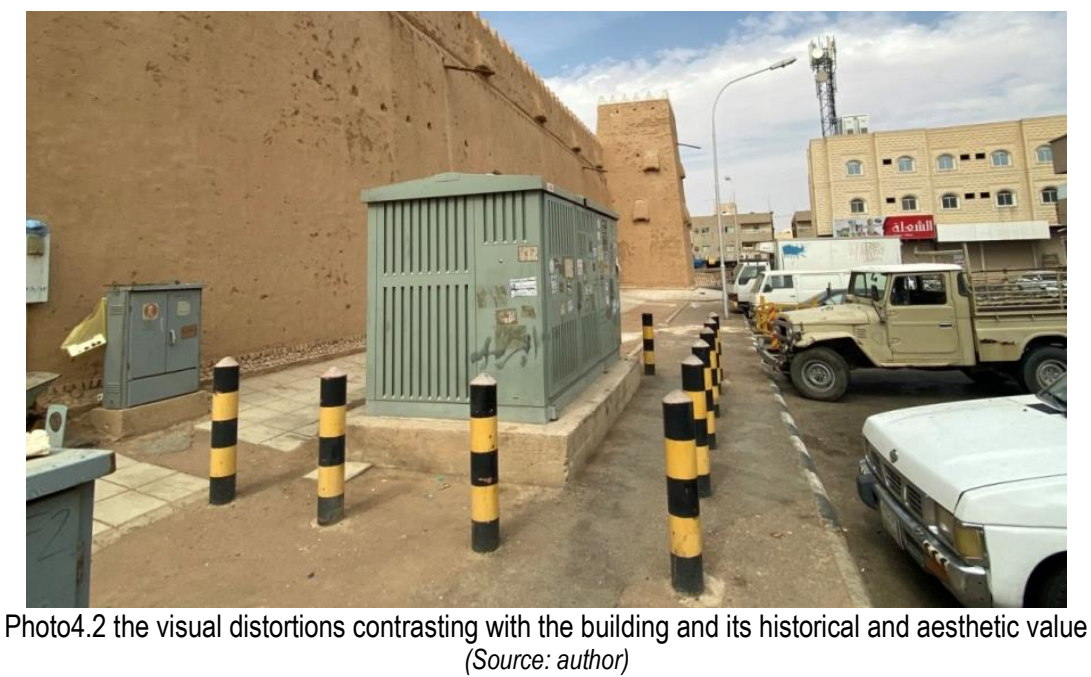

Al Qieshlah palace is situated in the middle of Hail city see photo 4.1. From the observation and the site visit to the case study area, it becomes clear that the Al Qieshlah was a significant historical building that is considered one of the most prominent landmarks in Hail city, the palace surrounded by commercial streets, modern facilities, and markets from all directions, all these effects contributed to giving an image and visual distortions contrasting with the structure and its historical and aesthetic value. It can be deduced that palace's surrounding area is suffering from a loss of archaeological significance, as the area surrounding was treated separately from the historic building. As shown in the photo 4.2

\section{b. The Plan}

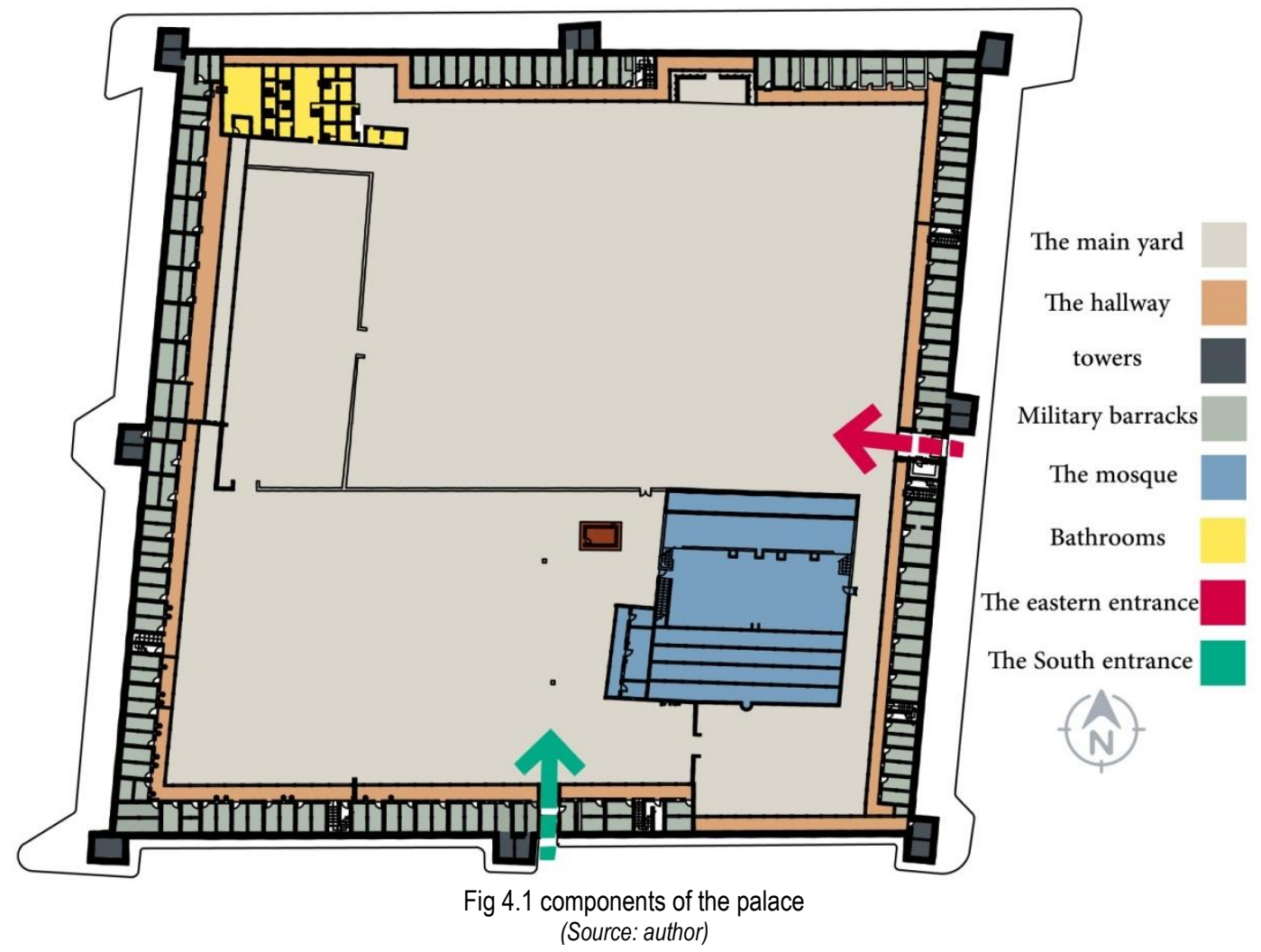

The palace takes a rectangular shape, with a total area of approximately 19,995 square meters, the castle consists of several different buildings which are the main components of the castle as shown in figure 4.1 and it is as follow:

1. An external wall in the shape of a rectangle $(142.72 \times 140.10 \mathrm{~m})$ with eight Conical shaped towers with a base of $6.85 \mathrm{~m}$ they used as an observation and defence towers. Four of these towers are were set in the corners. The other four are distributed in the middle of each wall, when looking at these external walls a variety of decorations are arranged in a magnificent 
architectural display. These decorations are carried the fully expressing the aspects, and the architectural style of Najd region. Most of the decorations on the exterior walls and the towers are in poor condition. Photo 4.3 illustrates the poor condition of the decoration on the towers of the building.

2. There were two main entrances to the palace are located in the middle of the east and south façade of the castle. All its details and elements are in their original condition. See figure 4.1

3. The palace is designed around a central courtyard, surrounded by military barracks (rooms) stand with two floors, The courtyard is surrounded by a covered corridor that precedes the military barracks(rooms), grounded on a round colonnade. Most of these military barracks(rooms) were built of clay and in good condition. In contrast, some of them on the ground floor are in lousy condition as shown in photo 4.4. A clay wall is separating the courtyard stretched from east to west, and another separates this wall from the north to the south of it in a bad condition also as shown in photo 4.5 , those two walls have been added during the police work.

4. The mosque is located on the north-western side, it consists of two levels, the first level is neglected and in poor condition, while the space on the second level is used for prayer.
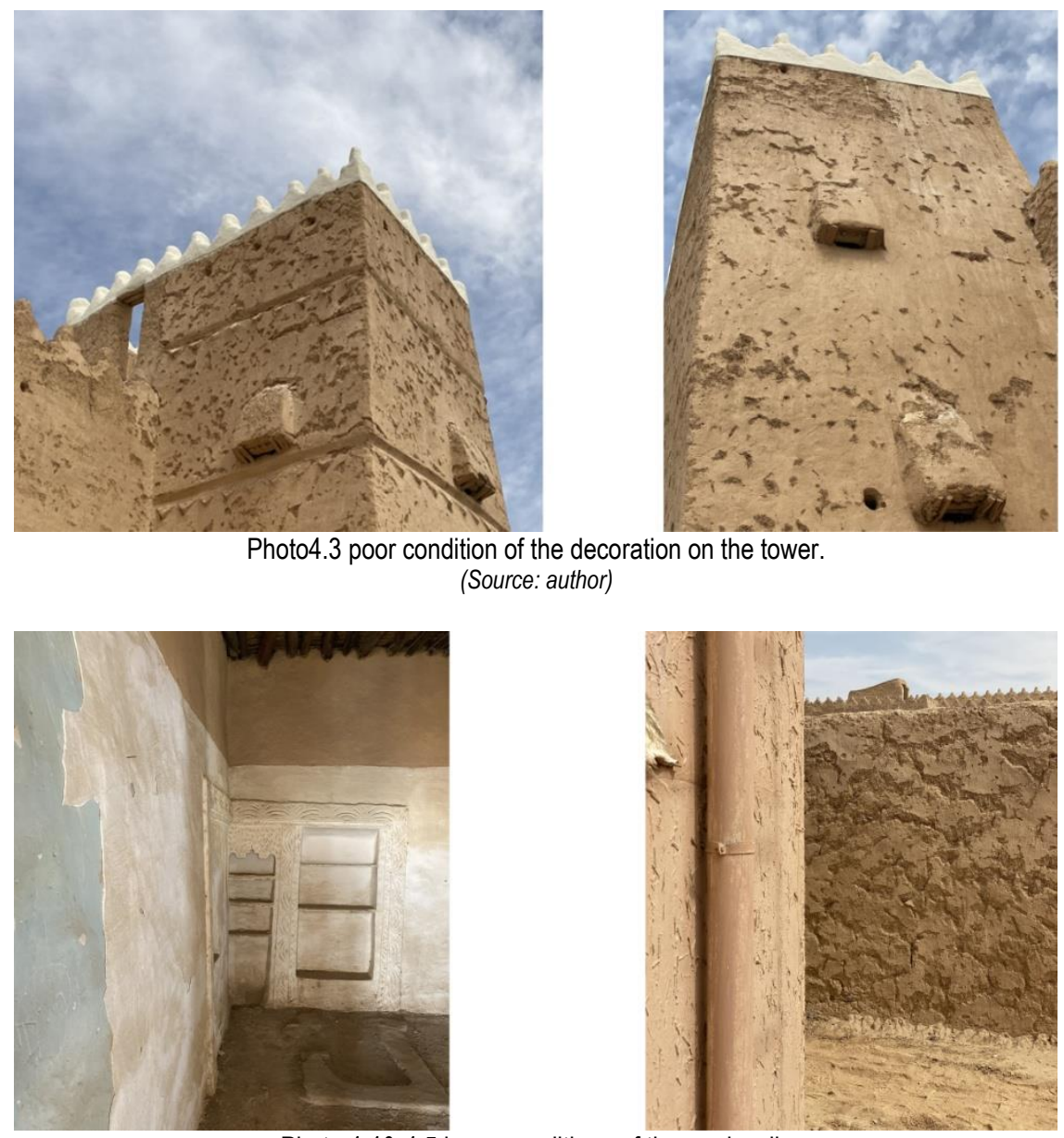

Photo $4.4 \& 4.5$ lousy conditions of the mud walls

(Source: author)

\section{c. Construction Material and Technique}

The palace was built on the traditional method using local materials, the materials used in construction are found to be locally available and mostly raw materials that are, where clay was used for walls and finishing works, while the stone used for foundations, palm leaves for ceilings, and timber used for doors and windows. Furthermore, it was discovered that the walls approximately are $9.5 \mathrm{~m}$ high, and the overall wall thickness is between 60 to 100 centimetres. When looking at these external walls, a variety of decorations are set in a magnificent architectural display. Also, these walls characterized by an abundance of defensive architectural elements, such as AlMazaghal is a defensive element, consisting of longitudinal cracks that spread along the walls, and Al-Tarma: It is a small building in the shape of a cone, and at the bottom, there are openings above the door to see who is standing with it from the outside. See photo 4.6. Rounded columns made of stone with two types of base used in the structures; the construction technique of the palace follows the architectural style of the Najd region. 


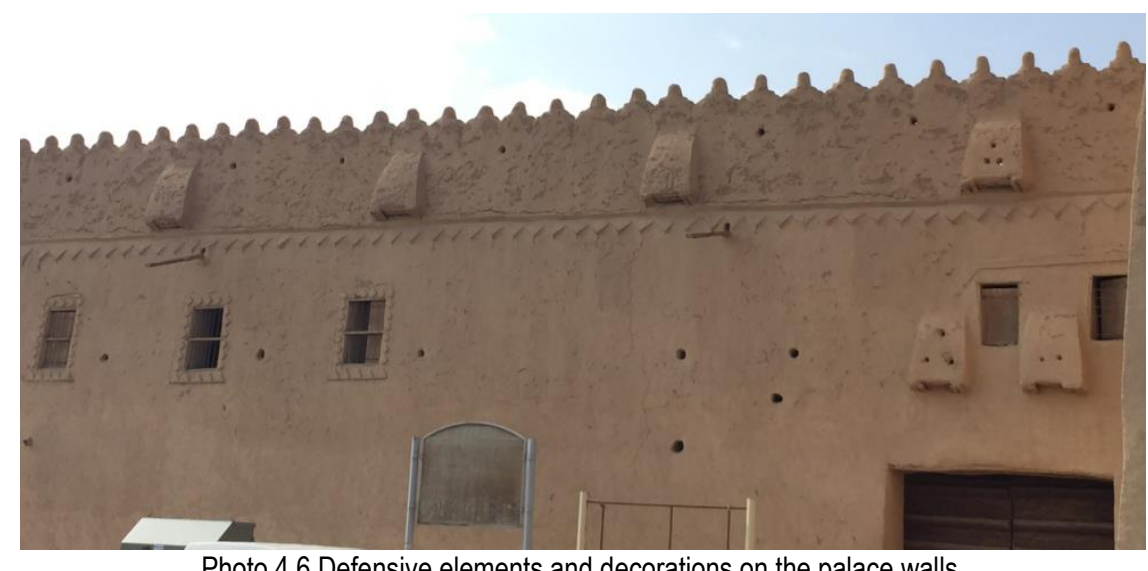

Photo 4.6 Defensive elements and decorations on the palace walls.

(Source: author)

\subsection{Case Study: King Abdul-Aziz Palace (Interview)}

This part presents and discusses the result of the analysis of the data derived from the structured and unstructured interview with the local authorities, specialists, academics, and officers, and those responsible for concepts and issues of heritage conservation. The questions posed to the participants according to their specialization, were classified into three different categories. The First group questions include the theoretical and practical aspects of preserving historical buildings and technical matters. In contrast, the second group consists of the most important problems faced by the historic buildings within the heritage conservation sites. However, the third group was about the implementation and application of conservation plans by the local authority.

When conducting an official interview with officials, and administrators, they admitted that when the responsibility of the restoration and supervision was assigned to the commission national heritage no documents and historical context were delivered of the building, such as photographs, and architecture documentary archives, which means that no records are available related to the building's conditions. Therefore, the reflection will be negatively on the conservation process. Thus, continuity and identity are not achieved through an authentically renovating process with complete care of every minute detail of the building.

Participants indicated that the building under the study is unique with architectural components to illustrate the richness of Historic area tangible heritage; this is evident when looking at the palace Inscriptions of a variety of decoration examples can be noticed, and these decorations are a combination of architectural and cultural significance within the heritage area. The palace also has a historical value represented by its construction being linked through the most prominent political figure in the history of the Saudi state, King Abdul-Aziz. Findings obtained from the professionals and academics that the palace suffers from some wrongly applied practices and the programs, conservation policies implemented by the local authorities with the aim of preservation.

By interviewing the head of the Municipality in Hail, he opined that the main problem faced by these historical buildings was the inconsistency of conservation policies and the lack of clear programs. The second problem was that most alternative maintenance programs did not meet the correct rules in preserving such historic buildings approved by international organizations, even though the state-approved monetary funds for such programs. The last problem was that the absence of an overall heritage conservation framework and guidelines added with no single body with overall responsibility for devising or implementing conservation policies makes the situation dangerous. Also, there is a need to provide further attention to aspects of the consistency of conservation policies by the local authorities, alongside elements of community involvement in heritage conservation and integrity of historic areas.

As for the interview conducted with the specialists and those who are responsible for concepts and issues of heritage conservation, they indicated that it was since the beginning of the year $1967 \mathrm{AD}$, the building has been used in many ways, which negatively affected the structure and preserving its original shape, as many buildings that contributed to deforming the structure were created, such as the car maintenance unit in the northwest corner of the palace. In a later period, a clay building was built in the courtyard as a museum, then to the west of it a concrete building was constructed as administrative offices, and to the east of the museum, a concrete building was structured as a toilet. All these represent a loss of the cultural, architectural and historical value of the palace. Moreover, these additions in the building contributed to the downfall of some of the main elements which carry a distinctive historical and architectural dimension.

\subsection{Conclusion and Recommendations}

This paper presented the case study of the Hail Historic Palace (Al Qieshlah), for those interested in concepts and issues of heritage conservation, and enhanced the importance of conservation of architectural heritage in the Kingdom of Saudi Arabia. It is important to note that while carrying out this case study, the study found out that there are no accurate drawings and detailing documented of this historic building. Based on the results and findings from the data analysis, about study's aims, Firstly, It can be concluded that Hail Historic Palace (Al Qieshlah) a real critical example of a conservation process of historical Heritage buildings, is a symbol of the most phases' present king Abdul-Aziz kingdom at its peak. Secondly, by evaluating the restoration process that was applied, many problems appeared that negatively affected the building, due to the absence of correct preservation policies approved by international organizations. Thus, preserving the historic buildings, in their complex nature, is not an easy process, as it requires planning, financing, and the participation of a team of experienced professionals. Therefore, the results were contrary to what the preservation mechanism aims for; furthermore, the palace suffers from some wrongly applied practices, and the inconsistency of conservation policies, and the 
lack of 'clear' programs. Finally, there is a lack of awareness among the local authority on some policies imposed by the government regarding the historic buildings. Therefore, the study recommends documenting these historical buildings, through specialized technical cadres, cooperating with colleges of architecture in Saudi universities to adopt programs in urban heritage, and hold training and educational courses that graduate local cadres specialized in restoration, and finally educating people through the media, newspapers and social media about the importance of this national heritage and its protection.

\section{Acknowledgements}

The authors would like to express their gratitude to Qassim University, Saudi Arabia, for providing administrative and technical support. The authors are also grateful to AMER International conference to present this paper on, AicQoL2021BukitTinggi,AMER International Conference on Quality of Life, BukitTinggi, Malaysia, 17-18 Mar 2021

\section{Paper Contribution to Related Field of Study}

The paper is considered a first contributed to documenting one of the historic buildings that carry a symbol of architectural and aesthetic values that suffer from some wrongly applied practices, and the inconsistency of conservation policies, and the lack of 'clear' programs. Also, the study contributes to documenting the evaluation of the current policies applied to these historical buildings, so that they should be avoided in any future restoration work. In addition, the study contributes to drawing the attention of the responsible authorities on the importance of these buildings and the way to preserve them as stipulated in international charters.

\section{References}

Al-KhamisN.A.(2011).Emergingvoicesof heritagepreservation in AlBalad, Jeddah: mappingviewsofkeyplayersandsocialactors. Researchandheritage. ResearchpapersfortheNationalBuiltHeritageForum(first edition), theSaudiCommissionforTourismandAntiquities. Jeddah, SaudiArabia, 14-16 November.

Al-Rashed, S. b. (2002). Symposium on archeology in the Kingdom of Saudi Arabia. Historical sites in Saudi Arabia (pp. 39-92). Riyadh: Ministry of Education, Agency for Antiquities and Museums.

AISaud, N. b. (2013). Impact of urban heritage conservation policies on historical sites in Saudi Arabia. Riyadh: SCTA.

Alyan, J. S. (2005). Preserving cultural heritage towards an Arab school to preserve and manage cultural heritage. Kuwait: National Council for Culture, Arts and Literature.

Aziz, R. A. (2017). HERITAGE CONSERVATION: AUTHENTICITY AND VULNERABILITY. Kajian Malaysia , 39-59.

Bagader, M. A. (2016). The Evolution of Built Heritage Conservation Policies in Saudi Arabia between 1970 and 2015: The Case of Historic Jeddah. Manchester : The University of Manchester (United Kingdom), ProQuest Dissertations Publishing.

Faqir, B.A. (2015). Masmak Palace is a symbol of monotheism and an icon of Najdi architecture. Riyadh : Saudi Commission for Tourism and National Heritage.

Feilden, B. M. (1994). Conservation of historic buildings. London: Butterworth Architecture.

King, G. (1998). The Traditional Architecture of Saudi Arabia. Iondon: I.B.Tauris.

Larkham, P. J. (1995). Constraints of urban history. Geographical Association , 111-124.

Majidi, B. H., \& Harith, K. A.-T. (2015, 12 12). Sustainable preventive preservation of the historic building. The Iraqi Journal of Architecture, pp. 307-327.

Mason, P. (2015). Tourism Impacts, Planning and Management. London: Taylor and Francis.

Osuala, A. E. (1982). Introduction to Research Methodology. Onitsha: Africana-FEP Publishers, .

SCTH. (2015).Architectural Heritage architectural identity and heritage of national. Riyadh: Saudi Commission for Tourism and National Heritage

SCTH. (2013).the Custodian Of The Two Holy Mosques Cultural Heritage Program. Riyadh: Saudi Commission for Tourism and National Heritage vision2030. (2016, 04 25). https://www.vision2030.gov.sa/download/file/fid/422. Retrieved 01 08, 2021, from www.vision2030.gov.sa. 